\title{
PROFESSIONAL TRAINING OF PHYSICAL EDUCATION SPECIALISTS: THE HISTORICAL ASPECT (end of the 19th - the beginning of the 20th century)
}

\author{
Tetiana Dereka \\ ORCID iD 0000-0003-0998-1821 \\ Doctor of Pedagogical Sciences, Associate Professor \\ Associate Professor of Physical Culture Theory and Methodology Department \\ Sumy State Pedagogical University A. S. Makarenko University \\ 87 Romenska Str., 40002 Sumy, Ukraine \\ 24tetiana01@ukr.net
}

\section{ABSTRACT}

The article describes the peculiarities of physical education specialists'professional training in the period from the end of the XIX to the beginning of the XX century. The professional activity of P. Lesgaft, O. Butowsky, I. Boersky, O. Anokhin as the founders of the national physical education was investigated. The methods of Lesgaft, Butovsky, Bobersky, Anokhin, aimedtoa person'sharmonious development and findingthe solution of physical education specialists' professional training problem, while each of them set specific tasks and offered their own means of solving them, were characterized. The professional training of physical education specialists is described in the historical aspect. The characteristic features of national physical education and sport specialists' professional training systemformation and development period in Ukraine in the twentieth century are defined. The first specialized physical education and sports pedagogical institutes of the beginning of the 20-th century are mentioned.

Key words: harmonious development; professional training; physical education specialists; physical education; physical education professional training.

\section{INTRODUCTION}

Today the actual problem is the quality of the acquired knowledge and skills and so the competitiveness of the graduate within the European educational space. The state, its system of education set and sets for the teacher certain goals and objectives as well as put forward new requirements for his personality. Concerning this the problem of future physical educationteacher'sprofessional image forming becomes important, which is conditioned by theoretical and practical tasks of a new type specialist's professional activity improvingwho orients in the modern world, where self-realization in the profession is a constant need of the individual. Modern specialists require a high level of activity, autonomy, flexibility, nonstandard thinking, general and professional culture (Quennerstedt, Larsson, 2015). The main focus is on the new generation of creative, professional and competent pedagogical workers preparation. Thus, the leading ideas of the positive historical experience of the physical education and sport specialists' professional training national system formation and development can be used for the reformation of the modern Ukrainian physical education system. 


\section{BACKGROUND}

Professional training of future specialists in physical education and sports is considered in works of native scientists in the following areas: specialists' readiness to the professional activity forming (M. V. Dutchak, O. N. Nosko, V. G. Savchenko, B. M. Shiyan); Ttheoretical and methodological principles of physical education as a pedagogical process (O. S. Kuts, L. P. Suschenko), in particular aimed at the preschool age children'shealth forming (E. S. Vilchkovsky, N. E. Pangelev), pupils (H. F. Denisenko, T. Yu. Krusevich, N. V. Moskalenko) and student youth (O. D. Dubogay, I. M. Medvedev, E. N. Pristup); physical education specialists' professional training in higher educational institutions (O. Ju. Azhippo, R. V. Klopov, A. P. Konoh, O. V. Tymoshenko); general theory of training of athletes (G. M. Arzyutov, O. Ts. Deminsky, S. S. Yermakov, V. M. Platonov, Ju. M. Shkrebtiy); the philosophy of sports (S. N. Bubka, M. M. Bulatova) (Dereka, 2017, p. 2).

Therefore, it is relevant to study the physical education specialists'professional training in the historical aspect, which has not been yet sufficiently studied today, that set the purpose of the article.

There is the level of person' physical condition development as well ashis motor qualities, readiness for professional, social and military activitiesalways,at each historical stage of society development, considered to be very important. So let us consider the main stages of the physical education development in the late nineteenth and early twentieth centuries, which contributed significally to the process of specialists'professional training within the field.

There were Georg Demini (1850-1917) and Petr Frantsevich Lesgaft (18371909) among physical education field specialists, who worked on the movements formsscientific substantiation.

G. Demeni, basingon the analysis conducted, developed the following system of physical exercises requirements (Dyba, Nesterova, Columbet, 2011, p. 8): 1) physical exercises must be dynamic; while staticand unnatural provisions must be avoided; the speed of motion must be inversely proportional to the mass of the moving body; for example: exercises for hands should be performed with greater amplitude, and with the feet and the body at a lower speed and scale; 2) in order to achieve a positive effect, motion should be done with a finite amplitude; it is impossible artificially, on the half way interrupt exercises; if one group of muscles strains to the maximum reduction, then the opposite muscles need to relax as much as possible; 3) movements must always be natural and widespread, not sharp, as in the old gymnastic systems; 4) those muscles that do not participate in movements, in the process of doing exercises should be completely relaxed; 5) when learning the exercises, you always need to progress from simple to complex, from lighter to heavier, from the known to the unknown.

P. Lesgaft (1837-1909) studied physical education in terms of the social role of physical culture and was the founder of the following theory (Theory and Methods of Physical Education, 2012, p. 15): 1) the systems of physical education is subject to the physiology laws; 2) in parallel with the physiology development it is constantly necessary to review and develop physical exercises; 3) physical education is a necessary means of a harmoniously developed person'sforming; 4) harmonious development is based on the unity of the physical and spiritual forces of human and takes place with the leading role of consciousness; 5) education 
of physical education, in essence, is a partial transfer of educational material accumulated in the course of history; 6 ) normal level of physical development can be achieved only with a scientifically substantiated "physical education" system; 7) educational material derived from the scientific system of "physical education" does not cover the whole treasury of knowledge, but only those types of movements that are easy to assimilate at school age: walking, running, jumping, throwing, fighting, arbitrary exercises, games, tourism; 8) education is a natural process of pedagogy. In the course of training, the great attention should be paid to the gradualness, consistency, age characteristics of the person and the principle of priority.

The Russian education system reformation in the late nineteenth and early twentieth centuries did not affect significantly the development of schoolchildren'sphysical education system. There were marches, free movements, exercises with sports equipment, and games for the junior classes or sports for the elders practicedin schools. But the only system of physical education, as well as the only system of physical culture specialists'training didn't existed. Therefore, the pedagogical and sports community perceived advanced ideas about the physical development of man and his natural abilitieswith great interest.

G. I. Prikhodko notes that there were native authors' developments appeared during this period, as following: "Physical Education System" P. Lesgaft (1894), "The system of gymnastic exercises for civilians educational institutions" by O. Butovsky (1891), "The Ukrainian System of Body Building" by I. Boersky (1901), "Natural System of Physical Exercises. Russian Gymnastics System" by A. Anokhin (1910) as a result of the progressive experience study and due to longlasting scientific disputes (Prykhodko, 1999, p. 74). The aforementioned methods were aimed at person'sharmonious development and on the physical education specialists'professional trainingproblem solution, with each goal setting specific tasks and assuming their own means of solving them.

According to A. V. Shabunin there was 2-year training and gymnastics courses officially opened by P. F. Lesgaft at the Second Petersburg Military Gymnasium in September, 1877. P. F. Lesgapte lectured on anatomy and led all practical classesof the 2-nd year including gymnastics and fencing there. Practical tasks in physics, chemistry, hygiene and anatomy were conducted in laboratories and offices of the Medical-Surgical Academy, and the physiology course of lectures was delivered by I. Sechenov (1829-1905). His researches opened the way to the knowledge of the general laws that led to the formation of a new view ofphysical education and sports training issues (Shabunin, 1989, p. 73).

One of the founders of physical education at that time was Alexei Butovsky (1838-1917), according to V. Draghi and M. D. Zubaliy, a member of the first composition of the International Olympic Committee (IOC) in 1894, the representative of Russia on I Contemporary Olympic Games in Athens in 1896; a prominent theorist and practice of physical culture movement. After the "Lesgaft's Courses" closure by Russian military minister I.S. Vannovsky, Colonel O. D. Butovskii was charged with the creation of "other gymnastics courses" (Butovskii, 2007, p. 143). Researchers state that, as a founder of the scientific system of military personnel physical education O. D. Butovsky understood that a person is both a holistic organism and a personality at the same time. While working at the Main Department of Military Educational Institutions, O. D. Butovskii was the first to substantiated theoretically the necessity of obtaining military not only general but also special physical education education, 
linking it with the formation of natural motor skills (running, walking, throwing, etc.) due to the genetic program of human'sphysical development and applied physical training, characteristic of a particular professional activity (military, industrial). Delivering history, theory and method of physical exercises, O. D. Butovsky tried to encourage the listeners to form the best qualities that are necessary to the thinking military man: the desire for new knowledge, love for work, thirst for knowledge, thirst for knowledge, awareness of one's own human dignity. He convincingly promoted and implemented in the life of the military the principle of a comprehensive and harmonious development of the officer's personality (Zubaliy, Zbaliy, 2005, p. 49).

The works of O. D. Butovsky "What is Physical Education?", "Body Exercises as a Subgect of Teaching", "General Rules for Teaching Body Exercises", "From Readings on the History and Method of Body Exercises", "Notes on the History and Method of Body Exercises", "Educational Properties of Body Exercise", promoted the ideas of physical education in Russia and were valuable tools not only for the students of the Main gymnastics and fencing school, but also for everyone who was interested in the issue of physical education. O. B. Sunnyk notes that "Butovskii went on into understanding some aspects of physical education further and deeper than Lesgaft, as well as many other authorities of that time" (Butovskii, 2007, p. 204).

The basis for the physical education theory development in Ukrainian lands, which were part of the Russian Empire at that times, became the active study of foreign pedagogical experience in the field of physical education, which was taken up in the 1930's. At the same time, teachers and doctors, in particular O. Anokhin, O. Butovsky, O. Dukhnovich, P. Lesgaft, S. Miropolsky, E. Pokrovsky, and others led discussions about tasks, principles, methods, means and organizational forms that should form the basis of the nativephysical education system, and about the system of physical education specialists'professional training (Tsos, 2005, p. 21).

Ivan Bobersky (1873-1947), according to O. M. Vacseba, was the first Ukrainian teacher to organize training courses for skilled teachers of locomotives (movement), who attracted wide circles of cities and villages public to physical culture, worked on the popularization of the Sokolsky movement and promoted it among different segments of the population. I. Bobersky developed the sporting terminology used by all the teachers of locomotives (movement) at that time. He was the first to organize women's sports and gymnastics associationson the territory of Ukraine. I. Bobersky was called "the father of the Ukrainian body education" during his lifetime (Vaatsba, 1997, p. 165).

The principles of the Sokil education system are still unchanged in the modern system of physical education (Romanchik, Savka, 2013, p. 5): the principle of a comprehensive development of personality; the principle of patriotic education; the principle of wellness orientation. Sokil (falcon) idea absorbed the best experience of the Swedish, German, French and other systems of body-forming and played an important role in the life of many Slavic peoples at the end of the XIX century; it attracted by its democracy, a harmonious combination of spirituality and corporeality, and contributed to national self-formation. I. Bobersky sought the ideal of a harmoniously developed personality in order to educate the whole nation, to raise the level of its national development, activation and unity.

According to T. Gh. Dyba and T. V. Nesterova, I. B. Bobersky actively taked on the publishing business for educational and training processes improvement. 
According to the scientists, there were no textbooks for the physical education specialists' training in Lviv at that time, so I. Bobersky at his own expense published the first textbooks on gymnastic exercises, sports games: "Fun and games of motion" (1904-1905), "Kopanymyach" (1906), "The Value of Moving Societies" (1909). In general there were numerous textbooks for native teachers of the locomotives(movement) published, such as: "Motoring and Games", "Kopanymyach”, "Free Manual Exercises", "On the Movement”, "New Ways to Bodybuilding", "Popular exercises", "Ball games", "Riding on the wings", "Track and field”, "Textbooks for English games" from 1903 to 1905 (Dyba, Nesterova, Columbet, 2011, p. 9). As the researchers noteIvan Bobersky published a textbook "Track and field athletics" in 1905 in which a special Ukrainian terminology of athletics appeared for the first time. The problem of the national terminology of physical culture and sportsfieldfunctioning and development remains one of the actual problems to nowaday.

The end of the nineteenth and twentieth centurieswas a very important period in the physical education system development on the Russian Empire territory, which was further developed in the Soviet period of Ukraine history, as well as during independence.

The diploma of physical education teacher was issued for the first time in Kyiv on the first courses of teacher's training in 1912 (Levitas, 2012, p. 10).

F. L. Levitas notes that $\mathbf{O}$. K. Anokhin was well aware of the key role of ateacher in the educational process, thus initiated and organized special courses for physical education teachers in order to improve their qualifications. Together with the doctor V. Kramarenko, O. Anokhin developed a program of teachers'courses. According to F. L. Levitas, the materials of the Central State Cinema and Photo Archives of Ukraine named after G. S. Pshenichny show that the first such courses were held in Kiev in 1912, and O. Anokhin was its first graduate director. According to the author, for the first time the program of courses provided, in addition to stroke training and gymnastic exercises, work on special sports equipment, athletics and sports games, a large theorycourse of pedagogy, anatomy, physiology and hygiene. The course process ended with examinations in basic disciplines (theory and practice) (Levitas, 2012, p. 11).

As G. I. Prykhodko notes, O. K. Anokhin especially took care of the problem of organizing physical culture personneltraining. The training of gymnastics teachers, in his opinion, was "a requirement of science, life and society". Assessing the situation in the country, the teacher emphasized: "We have the gymnastics teacher who can be anyone: it is just enough to say that he is a "sokil" (falcon) or a "tourner", or a member of any sports society and he could be given kids for gymnasticstraining(often irrespective of their gender). Without knowledge of anatomy, physiology, hygiene, pedagogy and other scientific disciplines, such a "teacher" is the head of the health and physical development of our children. Is that acceptable?" So, O. K. Anokhin was deeply convinced that it was necessary to trust the doing of younger generation education (and in particular physicaleducation) only to native specialists. "They, along with gymnastics, should instill national pride in kids" (Prikhodko, 1999, p. 163).

According to Ju. V. Cherpak, the realization of the physical education tasks in the native school, after O. K. Anokhin, could provide a system based on the best achievements of Swedish and Sokil gymnastics and their optimal combination with games and elements of following sports as trak and field athletics, fencing, 
wrestling, swimming, rowing, sliding, skiing and dancing. It is very important, in his opinion, to developfrom the childhooddiscipline (strike exercises), on the one hand, and on the other - solidarity (games), individuality (struggle) and aesthetic feelings (dances). In his system, O. Anokhin provided 50 and 30 minutes lessons. By content they should have been (Cherpak, 2012, p. 48):

- $\quad$ in case of 50-minute lesson: 1) marching exercises; 2) walking and running; 3) climbing; 4) exercises for the body (on the devices); 5) jumps; 6) throwing; 7) wrestling; 8) free exercises; 9) the game; 10) exercises for attention. After exercises $3,5,7,9$ it was necessary to introduce rest pouse and breathing gymnastics;

_ $\quad$ in case of 50-minute 30-minute lesson: 1) marching exercises; 2) walking and running; 3) climbing; 4) jumps; 5) throwing; 6) the game; 7) free exercises. After exercises 3, 5, 6 it was necessary to perform respiratory gymnastics.

According to F. L. Levitas, O. K. Anokhin was the first holder of the "Weightlifting Coach" diploma in Russia(1908). "Anokhin system" is still currently used by nowadays weightlifters (Levitas, 2012, p. 16). Should be also mentioned that O. K. Anokhin published numerous articles on physical education, sports and the Olympic movement in the leading scientific and pedagogical journals such as "Russian School", "High School Satellite", specialized editions "Physical Education and Sports", "Power and Health", "Russian sport" (Prikhodko, 2007, p. 121).

Thus, the characteristic features of the national system of physical education and sport specialists' professional training formation and development periodin Ukraine in the twentieth century (1890-1920) were: a prevalence of the course system in physical education and sports specialists'professional training; professional training of teachers and instructors of physical education, gymnastics instructors for military units, sports instructors; in the curriculum the benefits were given to general education, the study of medical-biological, special-practical disciplines; providing the Ministry of National Education with a leading role in determining the strategy and tactics in physical education specialists'professional training, developing a legal framework for the activities of educational institutions of various forms of ownership.

As I. R. Sviestnik notes, there were specialized sports and sports pedagogical higher educational institutions opened- such as the Central State Institute of Physical Culture in Moscow (1918) and the Institute of Physical Education named after. P. F. Lesgaft in Petrograd (1919) in the first years of the USSR (Svistelnyk I. R., 2008, p. 4). There were following scholars and educators as V. V. Gorinevsky, M. F. Ivanitsky, A. N. Krestovnikov, I. M. Sarkisov-Serazini, A. D. Novikov, P. A. Rudyk took part in physical education system formation in this period.The First All-Russian Congress of Physical Education and Pre-Preparatory Training heldin 1919 planned to begin a systematic work on the childrenphysical education, the creation of sports clubs, and the expansion of the network of educational institutions for the personneltraining. According to Y. O. Tymoshenko, since the end of the 1920's all spheres of physical culture acutely lacked skilled personnel. Instructors'training courses did not meet the needs of specialists either quantitatively or qualitatively. Thereforethere was a radical shift in the system of scientific work and physical education specialists'training in 1930. This was due to the openindof following institutions: the Ukrainian Physical CultureResearch Institute,the All-Ukrainian Institute of Physical Culture in Kharkiv, as well as technical colleges of physical culture in several Ukrainian cities (Tymoshenko, 2011, p. 12). 


\section{CONCLUSIONS}

Thus, the period of the end of the nineteenth and early twentieth centuries is characterized by the Ukrainian physical educationsystem formation. Systems of physical education developed by P. Lesgaft, O. Butovsky, I. Bobersky, O. Anokhin were among the best in the worldfor one time, and many of provisions have not lost their significance even nowadays, although they, unfortunately, did not become the basis for national physical educationin Russia, since the tsarist government did not have a state program in this area of education, and the country had neither qualified teachers nor a special material and technical base. This period, the end of the nineteenth and the beginning of the twentieth century, was a very important stage in the vocational training system development in Ukraine. Subtitles to the content of the study is the development of industrystandardsforphysical education specialists' professional training using the foreign experience of the EU and the US.

\section{REFERENCES}

Butovsjkyj, O. D. (2007). Vybrani tvory [Selected Works]. Uporjadnyky V. V. Dragha, M. D. Zubalij, drughe vydannja, pereroblene i dopov.: Kyiv, Ukraine: VAT «Polighrafknygha».

Vaceba, O. M. (1997). Narysy z istoriji zakhidnoukrajinsjkogho sportyonogho rukhu [Essays on the history of the Western Ukrainian sports movement]. IvanoFrankivsjk, Ukraine: Lileja-NV.

Dereka, T. Gh. (2017). Akmeologhichni zasady nepereronoji profesijnoji pidghotovky fakhivciv fizychnogho vykhovannja [Acmeological principles of physical education specialists' lifelong professional training] (Extended abstract of Doctor's thesis, Borys Grinchenko Kyiv University, Kyiv, Ukraine).

Dyba, T. Gh. (2011). Vstup do specialjnosti: fizychne vykhovannja [Introduction to specialty: physical education]. Modulj 2: navch. posib. T. Gh. Dyba, T. V. Nesterova, O. M. Kolumbet. Kyiv, Ukraine: Borys Grinchenko Kyiv University. Zubalij, M. D, \& Zubalij, V. M. (2005). O. D. Butovsjkyj - pershyj ukrajinecj u Mizhnarodnomu olimpijsjkomu komiteti [O. D. Butovsky is the first Ukrainian in the International Olympic Committee]. Fizychne vykhovannja v shkoli. $4,47-50$.

Levitas, F. L. (2012). Kyjivsjka doba likarja i pedaghogha Oleksandra Anokhina [Kyiv's Post Doctor and Teacher Alexander Anokhin]. Fizychna kuljtura $i$ zdorov'ja ljudyny: istorija, sjoghodennja, majbutnje (do 100-richchja pershogho kyjivsjkogho dyploma vchytelja fizychnoji kuljtury): proceedings of the International Conference (October 18-19, 2012). Ministerstvo osvity i nauky, molodi ta sportu Ukrajiny, Kyjiv. un-t im. B.Ghrinchenka, In-t spec. pedagh. NAPN Ukrajiny, Blaghod. fond. spryjan. rozv. osv. im. B. Ghrinchenka. V. O. Ohneviuk, L. L. Khoruzha, N. M. Vinnikova, T. Gh. Dyba, T. V. Nesterova (Eds.). Kyiv, Ukraine: Borys Grinchenko Kyiv University.

Prykhodjko, A. Y. (1999). Problema fyzycheskogho vospytanyja lychnosty $v$ otechestvennoj pedaghoghycheskoj zhurnalystyke (vtoraja polovyna XIX nachalo $X X \quad$ v.) [The problem of physical education of the personality in the domestic pedagogical journalism (second half of the nineteenth and the beginning of the twentieth century)] (Doctoral dissertation, HNPU named after G. S. Skovoroda, Kharkiv, Ukraine). 
Prykhodjko, A. Y. (2007). Zhurnal «Krasota y syla» (1913 gh.) y egho rolj v razvytyy obshhestvennogho fyzkuljturnogho dvyzhenyja v Ukrayne [The magazine "Beauty and Strength" (1913) and its role in the development of the public physical culture movement in Ukraine]. Pedaghoghika, psykhologhija ta medyko-biologhichni problemy fizychnogho vykhovannja i sportu. 12, 118-122.

Romanchyk, Kh., \& Savka I. (2013). Istorychni vikhy zhyttjevogho shljakhu Ivana Bobersjkogho [Historical milestones of the life course of Ivan Bobersky]. Proceedings of the All-Ukrainian Conference. Lviv, Ukraine: Vydavnychyj centr LNU im. I. Franka.

Svisteljnyk, I. R. (2008). Osoblyvosti formuvannja systemy vyshhoji fizkuljturnoji osvity ta jiji informacijnogho zabezpechennja u 20-40-kh rokakh XX stolittja [Features of the formation of the system of higher physical education and its information provision in the 20-40-ies of the XX century]. Teorija i metodyka fizychnogho vykhovannja. 2, 3-6.

Teorija i metodyka fizychnogho vykhovannja [Theory and methods of physical education]. (2012). U 2-kh tomakh. T. 1. Zaghaljni osnovy teoriji i metodyky fizychnogho vykhovannja. T. Ju. Krucevych (Ed.). Kyiv, Ukraine: Olimpijsjka literatura.

Tymoshenko, Ju. (2011). Stanovlennja systemy pidghotovky pedaghoghichnykh kadriv u sferi fizychnoji kuljtury [Formation of the system of training pedagogical staff in the field of physical culture]. Fizychne vykhovannja, sport i kuljtura zdorov'ja u suchasnomu suspiljstvi: zbirnyk naukovykh pracj. 2 (14), 8-16 (ukr).

Cjosj, A. V. (2005). Rozvytok fizychnogho vykhovannja na terytoriji Ukrajiny z najdavnishykh chasiv do pochatku XIX st. [Development of physical education on the territory of Ukraine from the ancient times to the beginning of the nineteenth century] (Extended abstract of Doctor's thesis, Kharkiv State Academy of Physical Culture, Kharkiv, Ukraine).

Cherpak, Ju. V. (2012). Vnesok O. K. Anokhina ta V. K. Kramarenka u rozvytok fizychnogho vykhovannja molodi v Kyjevi (pershe desjatylittja XX st.) [Contribution of O.K.Anokhin and V.K.Kramarenko to the development of physical education of youth in Kyiv (the first decade of the twentieth century)]. Fizychna kuljtura i zdorov'ja ljudyny: istorija, sjoghodennja, majbutnje (do 100-richchja pershogho kyjivsjkogho dyploma vchytelja fizychnoji kuljtury): proceedings of the International Conference. Kyiv, Ukraine: Borys Grinchenko Kyiv University.

Shabunin, A. V. (1989). Lesgaft v Peterburge [Lesgaft in St. Petersburg]. Moscow, Russia.

Quennerstedt, M., \& Larsson, H. (2015). Learning movement cultures in physical education. Sport, Education and Society. Published online: 21.01.2015. doi: 10.1080/13573322.2014.994490. 